\title{
PRODUCTION OF ŠAR CHEESE - DEVELOPMENT OPPORTUNITY FOR ŠTRPCE MUNICIPALITY
}

\author{
Maja Mladenovićl, Radica Bojičić ${ }^{2}$ \\ *Corresponding authorE-mail: majaavondama@yahoo.com
}

\begin{abstract}
A R T I C L E I N F O
A B S T R A C T

Original Article

Received: 04 March, 2018

Accepted: 09 July, 2018

doi: 10.5937/ekoPolj1803929M

UDC 637.3:330.34(497.11Štrpce

Keywords:

Šar cheese, Municipality of Strpce, agricultural and food sector, rural development, livestock breeding

As a result of the climate in which it is produced, as well as its recognizable taste and quality, the Šar cheese is a high demand product on the market of Kosovo and Metohija. The authors will, based on the research presented in this paper, give an overview of the production and the main carriers of the Šar cheese production. It will also present how Šar cheese production may be used in helping people survive in Sirinićka Župa. This paper would also, through direct surveys, observe perceptions and attitudes of the inhabitants of this region and provide practical guidelines on the production of the Šar cheese as development potential of the municipality of Štrpce, and recommend further agricultural reforms and tourist capacities of this region.
\end{abstract}

JEL: O13, R20

(C) 2018 EA. All rights reserved.

\section{Introduction}

Cheese production is almost as old as the civilization itself. According to the historical data, the production of this dairy product started in $8000 \mathrm{BC}$, while, thanks to the development of the civilization of the ancient Greece, it was raised to a higher level and has become a true art. The beginning of the industrial cheese production dates back to the beginning of the 19th century and Switzerland, but the real industrialization in production and purchase began in America in 1851. Nowadays, cheese is one of the main dairy products that is widely used in everyday consumption. It is produced in about 1.000 different variations, mostly in the United States, Europe, Australia and New Zealand (Table 1). The document World Cheese Market 2000-2020, prepared by PM Food \& Diary Consulting (2014), stated that the market share of the European Union and the United States was 70\% of the global cheese production in 2012, and it is expected that the cheese production will have further dynamic growth by 2020 , when it will reach the amount of 16.6 million tons (MT).

1 Maja Mladenović, M.Sc., Ph.D. student in Faculty of Economics, University of Priština with temporary location in K. Mitrovica, Kolašinska no. 156, 38220 Kosovska Mitrovica, Serbia, Phone: 0290/70-295, E-mail: majaavondama@yahoo.com

2 Radica Bojičić, Ph.D., Associate Professor, Faculty of Economics, University of Priština with temporary location in K. Mitrovica, Kolašinska no. 156, 38220 Kosovska Mitrovica, Serbia, Phone: +38163/410-758, E-mail: radica.bojicic@pr.ac.rs

http://ea.bg.ac.rs 
Table 1. World cheese market 2000-2020

\begin{tabular}{|l|c|c|c|c|c|}
\hline \multicolumn{1}{|c|}{$\mathbf{1 0 0}$ MT } & $\mathbf{2 0 0 0}$ & $\mathbf{2 0 1 2}$ & $\mathbf{2 0 1 2 / 2 0 2 0}$ & $\begin{array}{c}\mathbf{2 0 2 0} \\
\text { (prognosis) }\end{array}$ & $\mathbf{2 0 2 0 / 2 0 1 2}$ \\
\hline EU-28 & 7,709 & 9,333 & $+21 \%$ & 10,606 & $+14 \%$ \\
\hline the rest of Europe & 266 & 291 & $+9 \%$ & 338 & $+16 \%$ \\
\hline CIS & 448 & 866 & $+93 \%$ & 1,072 & $+24 \%$ \\
\hline North America & 4,227 & 5,618 & $+22 \%$ & 6,720 & $+20 \%$ \\
\hline Oceania & 665 & 700 & $+5 \%$ & 930 & $+33 \%$ \\
\hline South America & 1,118 & 1,625 & $+45 \%$ & 2,067 & $+27 \%$ \\
\hline Asia & 293 & 456 & $+55 \%$ & 1,288 & $+187 \%$ \\
\hline Middle East + Africa & 744 & 1,512 & $+103 \%$ & 2,054 & $+36 \%$ \\
\hline Total world & 15,470 & 20,401 & $+32 \%$ & 25,075 & $+23 \%$ \\
\hline
\end{tabular}

Source: PM Food \& Diary Consulting, 2014

When talking about Europe, the leading countries in cheese production are Germany, France, Italy and the Netherlands. There are many types of cheese produced in Europe, including: Appenzeller, Cheddar, Edam, Emmentaler, feta, fontina, Gouda, Gorgonzola, Grana Padano, Gruyere, halloumi, kashkaval, Camembert, mascarpone, manchego, mozzarella, Olomouc, Parmesan, Pag cheese, Pecorino, ricotta, Romadur, Tilsit, Trappist. Perhaps less widely known, but certainly not with less quality, are cheeses from the Republic of Serbia. On account of geographic, climatic and vegetation diversity, the production of autochthonous cheese has been developed in Serbia (Mladenović K., et al., 2017). There are several autochthonous types of cheese originated from this area, and their names indicate the place of their origin: Pirot, Sombor, Kraljevo, Homolj, Sjenica, Zlatar, Pljevlja, Mileševa, Šar cheese, etc. When it comes to cheese production, Serbia is not far behind developed countries of the European Union. According to Eurostat Milk and Milk Product Statistics (2017), Serbia is ranked 13th, ahead of some developed European countries such as the Czech Republic, Belgium, Sweden and Finland, but also some countries in the region: Bulgaria, Hungary, Croatia and Romania.

Cheese production is spread all over Kosovo and Metohija and it presents an important part of the traditional food (Butuqi et al., 2017). According to the data of the Ministry of Agriculture, Forestry and Rural Development of the Provisional Self-Government in Priština from 2015, 14.289 households are involved in the cheese production. The total cheese production in that year was 17900 tons, which required around 107900 tons of milk. One of the most famous type of cheese in this area is the Šar cheese, which is produced in households in the villages of the municipality of Štrpce. In the area of this municipality, which is characterized by exceptionally preserved environment, clear rivers and streams, as well as clean mountain air, the cheese is produced in the traditional way that has been used since the ancient times. They are preserving the inherited tradition of our ancestors. Considering that "good reputation goes far...", the taste of this dairy delicacy is widely known and attracts more fans every day. Its popularity is also indicated by the fact that buyers pre-order cheese, because the production has been lower than the market needs for a long time. 
Due to the small number of researches done on the topic of the cheese production and generally about the municipality of Štrpce, especially after 1999, the intention of the authors is to correct that by promoting the municipality of Štrpce, especially the Šar cheese as the top positioned local specialty. An analysis made on the basis of the conducted research will provide an overview of the production state and sales of cheese in the municipality of Štrpce. The aim of this research is to illustrate how the livestock fund, technology and the involvement of household members influence the production of cheese, and whether the support towards the establishments of new small farms would improve production of Šar cheese and economic environment of the Municipality of Štrpce. Additionally, the paper would determine the potential for expanding the agricultural and tourism capacity of the region, and how the advancement of cheese production would contribute to improving the living standards and quality of living of the inhabitants of this region, as well as the perspectives for durable existence in economic terms. Also, the paper will give suggestions what measures the municipality of Štrpce and its farmers could take in order to follow the examples of successful countries, when it comes to cheese production.

The production of agricultural products has always been at the top of economic activities in the Republic of Serbia. Agricultural and food sector has a very important role in the economic development of the Republic of Serbia, considering its significant participation in domestic export (Đurić et al., 2017). Milk production is one of the essential sectors of Serbian agriculture, and therefore the survival of the whole production system is in the public interest (Zekić et al., 2016). Although according to Eurostat (Milk and Milk Products Statistics, 2017), the production is generally lower in Serbia than in more developed countries of the European Union (according to milk production, Serbia is ranked 31st place), there are tendencies of its growth. Growth is also expected in the consumption, especially of the healthy food, that is $100 \%$ organic products, but also those with low fat content or nonfat products. The situation in the Kosovo area is similar. The market of milk and dairy products in Kosovo and Metohija is one of the fastest growing in the entire agricultural field. Although import is largely responsible for the enrichment of the dairy products market, there are still products produced only in this region, which make up an important part of the offer on the Kosovo and Metohija market. Among these products, one of the most famous is the Šar cheese.

Cheese is one of the oldest food products with preservation based on fermentation, the most common and perhaps the oldest biotechnology (Bulajić et al., 2017). Mladenović K., et al. (2017) wrote that southeastern region of Serbia is one of the areas known for the traditional method of producing dairy products. In this region, the inhabitants produce one type of cheese made from unpasteurized cow's milk. Šar cheese is a hard cheese, produced in settlements below the Šar Mountains such as Štrpce, Opolje and Gora. The tradition of producing this delicacy is over a hundred years old and is passed from generation to generation. 
Table 2. Livestock breeding by districts

\begin{tabular}{|l|c|c|c|}
\hline \multicolumn{1}{|c|}{ Livestock type } & Priština district & Peć district & Prizren district \\
\hline Pigs & 10.934 & 9.068 & 4.204 \\
\hline Horses & 6.230 & 2.293 & 7.525 \\
\hline Mules & 53 & 150 & 644 \\
\hline Donkeys & 2.362 & 1.520 & 4.265 \\
\hline Cows and bulls & 50.600 & 20.774 & 20.010 \\
\hline Calves & 15.700 & 20.215 & 5.490 \\
\hline Oxen & 39.000 & 9.960 & 13.585 \\
\hline Buffalo & 3.930 & 2.070 & 3.550 \\
\hline Sheep & 149.640 & 62.297 & 15.031 \\
\hline Goats & 100.720 & 16.929 & 52.735 \\
\hline
\end{tabular}

Source: Mikić, 1988

The beginnings of livestock breeding in this area date back to the distant past. In the first half of the 19th century, livestock breeding was the most developed in the settlements on the Šar Mountain (Mikić, 1988). According to the book "Social and Economic Conditions of the Kosovo Serbs in the Nineteenth and Early Twentieth Centuries", as well as Petar Kostić, at that time the livestock units were counted in millions (Table 2).

The main livestock breeders in the northeastern part of the Šar Mountain, or as Mikić called them "Baš-Šari”, were Serbs from Sirinićka Župa, Sredska and Macedonia. The situation remained like this until the end of the 18th and the beginning of the 19th century, when this area of the Šar Mountain was inhabited by Albanians, who took over the leading position from Serbs. However, due to the circumstances that prevailed at that time (robberies, temporary work abroad, the emergence of new occupations such as tailors, blacksmiths and other crafts), the interest in livestock breeding declined. However, there are still households which livestock graze on the slopes of the Šar Mountain and which continue with the tradition of making cheese and other dairy products. All this, as well as the special type of cheese was mentioned in the famous "Constantinople Gazette". Despite the decrease of livestock breeding in the Šar Mountain, Constantinople Gazette from June 28, 1901 wrote that "Šar cheese conquered neighboring markets. This cheese is characterized by a yellow greasy color and a taste that no other cheese has, regardless of their production" (Mikić, 1988). This description can still be used for the cheese produced in the municipality of Štrpce.

In the beginning, Šar cheese was most commonly made from sheep's milk, and there were a few reasons for that: there were plenty of sheep, and they often went to graze in higher and more inaccessible parts of the mountain. They grazed autochthonous grass and medicinal herbs that gave milk and cheese a special flavor. With the increasing of the number of cows, cheese begins to be made from cow's milk as well.

The recipe for preparing this specialty of Sirinićka Župa has remained the same as it was a hundred years ago. This traditional, but also ecological method, implies manual cow or sheep milking, after which the fresh milk is strained and heated at a temperature of 30 to $40^{\circ}$ C. In order to make 1 kilogram of cheese, about 10 liters of cow or 7-8 liters of sheep's milk 
is needed. The next step is pouring the rennet into the heated milk. These products are used for the purpose of separating the fatty part of milk and whey. After the milk is left for a while with the occasional mixing, it is poured into a larger container with a gauze and strained. The cheese made this way is compressed in the gauze and compressed firmly in order to release all the liquid out and then it is left for a while. It is made in the form of round, flat balls, which are then dried in a dark place with good air flow. The most usual place for that is a terrace, attic or a specific chamber placed at the air flow points. The drying time is usually ten to twenty days and may be longer or shorter, depending on the season. After drying, a liquid for salting the cheese is being prepared. It is a mixture of water and salt (usually about 300-400 grams of coarse, sea salt should be dissolved in a liter of water) in which already dried and cut down cheese is put and left for ten days. After that the cheese is ready for sale.

The quality of such cheese is very high, since it is a hard, full-fat dairy product. As Mladenović K., et al. (2017) said, cheese is an excellent source of protein, fat, minerals (calcium, iron, phosphorous), vitamins and amino acids. Some of the nutritive values of different types of cheese are listed in Table 3. It can be seen in the table that high-fat hard cheese, such as Šar cheese, has a very high calorie value, protein and fat values, but no carbohydrates. According to these indicators, they can be compared with more famous types of cheese such as: Emmentaler, Gorgonzola, Gouda and Parmesan.

Table 3. Nutritional value of different type of cheese per $100 \mathrm{gr}$

\begin{tabular}{|l|c|c|c|c|}
\hline \multicolumn{1}{|c|}{ Cheese type } & Calories & Proteins & Carbohydrates & Fat \\
\hline Soft cheese & 73 & 14 & 4 & 1 \\
\hline Half-timed soft cheese & 103 & 12 & 3 & 4 \\
\hline Fat hard cheese & 347 & 20 & 0 & 30 \\
\hline Low-fat cheese & 78 & 12 & 3 & 2 \\
\hline Melted cheese (45\% fat) & 386 & 14 & 6 & 24 \\
\hline Hard cheese (45\% fat) & 372 & 25 & 3 & 28 \\
\hline Fresh cow cheese & 72 & 15 & 4 & 3 \\
\hline Emmentaler & 383 & 30 & 0 & 30 \\
\hline Gorgonzola & 360 & 20 & 0 & 30 \\
\hline Gouda & 367 & 27 & 0 & 30 \\
\hline Resinous cheese & 140 & 32 & 0 & 1 \\
\hline Melting cheese & 272 & 16 & 0 & 24 \\
\hline Parmesan & 367 & 34 & 0 & 34 \\
\hline Mozzarella & 227 & 20 & 0 & 17 \\
\hline Cheese from skim milk & 234 & 18 & 1 & 19 \\
\hline
\end{tabular}

Source: http://www.vjezbaj.com/kalorijska-tablica/, (June 06, 2018)

\section{Materials and methods}

The basic method used to collect data in this research is the method of direct survey. For this purpose, the original questionnaire with 15 questions was made, which, according to the authors, represent the state of production and sales of cheese in the municipality of Strpce in the best way. It involved issues related to the length of the cheese production, the number 
of livestock they own, the methods of cheese production, the involvement of the family in the work, the daily amount of milk, the weekly production and sales of cheese, the method of sale, price, sales satisfaction, competition, assistance to livestock farmers, the existence and plans for the production expansion. The order of the answers to the questions asked was based on the five-point response, so-called Likert scale. The answers were ranged from 1 to 5, where the least favorable or desirable response was marked with 1 , while the affirmative response or the highest offered value was marked with 5 . The research included 12 villages in the municipality, with a total of 50 livestock breeder, producers of Šar cheese. There are no official data on the number of households involved in livestock breeding in the municipality of Strpce. Based on the data from the field, available to the authors, this number is approximately 200 households. This confirms that a sample of 50 livestock breeders surveyed for the purpose of this research is very representative. Obtained survey data was processed in the IBM SPSS Statistics-version 23 software package and based on the results obtained a comprehensive linear regression analysis was performed. In order to ensure a more accurate presentation of the given topics, the methods of observation, descriptions, comparisons, analyzes, syntheses and others were also used. Due to the already mentioned fact that after 1999, there are no statistical data of the Statistical Office of the Republic of Serbia for the territory of Kosovo and Metohija, nor for the Municipality of Štrpce, the sources of the Municipality of Štrpce and the Ministries that are in the system of Provisional Self-Government in Priština were used, as well as the data from publications prepared by the international factors that have been operating in this territory for the last 18 years.

\section{Results}

The research that has been carried for the purposes of this paper has shown that nowadays fewer people are engaged in livestock breeding, but what is even more worrying is that these few livestock breeders have even fewer livestock. A survey conducted on a sample of 50 respondents, livestock breeders ( 25 male and 25 female) shows that majority of respondents, $66 \%$ of them, own only one livestock unit. $28 \%$ own two livestock units, and the rest of $6 \%$ owns from 3 to 10 livestock units, which represents a very bad statistic for this, once-so profitable branch of agriculture (Figure 1).

Figure 1. Livestock number in respondent households

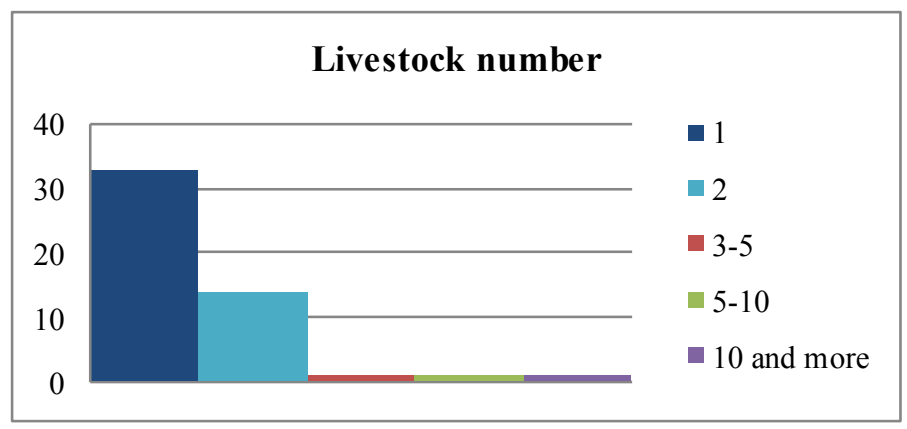

Source: authors' research 
More than half of the respondents ( $54 \%$ of them) have been involved in this business for more than a decade, while the number of those involved in the livestock breeding for a shorter period of time, up to 10 years, is much smaller. As already mentioned, cheese is mainly produced according to the traditional recipe, which is also confirmed by our research (66\% of respondents use this recipe). Organic production method, without additives, is used by $10 \%$ of the respondents, the same percentage uses different recipes, while $14 \%$ of them use a recipe in which citric acid is used. In the municipality Strpce, usually entire family is involved in the work with the livestock, because only such a job can be profitable. Previously, the participation of all family members was not questioned, both younger and older family members were equally involved in the field and in the stable. Nowadays, the situation is a bit different, the younger population is not so interested in working with the livestock, and if they work, they do the minimum. Basically, most of the work is done by the older family members. The majority of our respondents, $36 \%$ of them answered that only their spouses work, a quarter responded that the whole family was involved in the livestock breeding, a fifth of the respondents pointed out that children help them, while the negligible number of the respondents work without any assistance (Figure 2).

Figure 2. Structure of the sample according to family involvement in the process of production of the Šar cheese

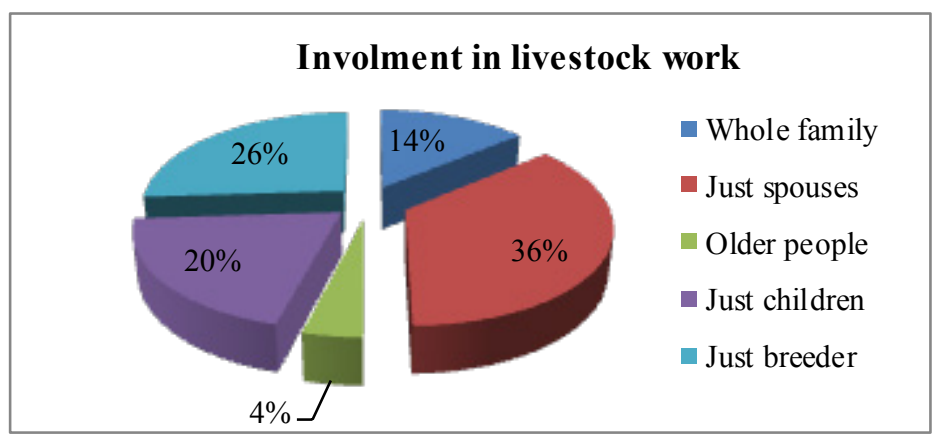

Source: authors' research

When it comes to the amount of milk obtained from cows, according to the majority of responses, it ranges from 5 to 20 liters, while fewer respondents replied that they daily milk up to 5 and over 20 liters. Of these quantities, the majority of our respondents (30\% and 26\%) produce between 3 and 4 , that is 5 to 6 kilograms of cheese. One fifth of all respondents produce more than $8 \mathrm{~kg}$, while the rest, $8 \%$ and $16 \%$ produce between 7 and 8, that is, between 1 and 2 kilograms (Figure 3). 
Figure 3. Milk and cheese production
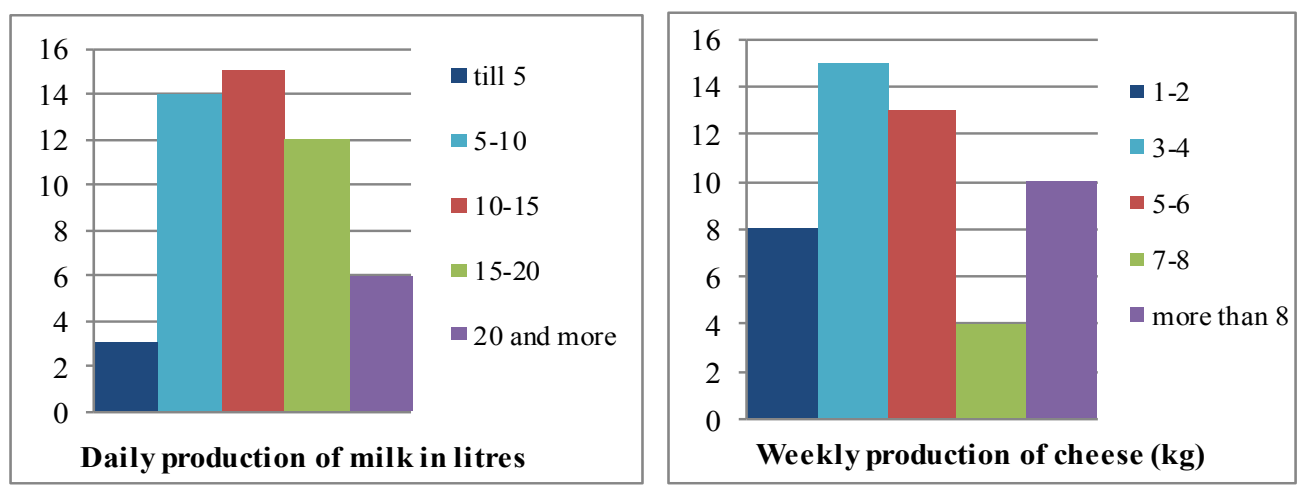

Source: authors' research

The respondents also answered the question of the weekly sale of cheese. The majority of respondents, $30 \%$ and $36 \%$ of them responded that they sell 1 to 3 , that is, 5 to 6 $\mathrm{kg}$ per week. A quarter of them do not sell cheese at all, while 14\% of them sell more than $7-8 \mathrm{~kg}$. It should be noted that, generally speaking, the situation regarding the sale of cheese is very favorable for the producers in the municipality of Strpce. Cheese is a very high demand commodity and it often happens that a buyer needs to wait longer to buy it, given the longer period of the cheese production. However, this is not the case with all producers. Some households have difficulties with the sale. There are more reasons for this, but above all, the most important is the customer loyalty. When customers buy cheese and are satisfied with it, they return repeatedly to the same producer, convinced that they will get the expected quality. Also, the cheese is purchased on recommendation, and there are also so-called "recognized producers" whose quality is not questioned. It's because quality is the most important feature for customers, even more important than the price. However, there are a lot more producers who are satisfied with the sale, which was also confirmed by our research. 18\% of them are completely satisfied with the sale, a quarter is partially satisfied, while others express a certain amount of dissatisfaction with the sale of cheese.

The cheese is usually purchased directly from the producer, and in order to get their favorite delicacy, customers are ready to go to the most remote villages in the municipality. When visiting the cheese producers, usually, along with local plum or honey brandy, they taste cheese, buy certain quantities of it, but also often buy other domestic products that are offered. Even $60 \%$ of our respondents use this method of selling cheese, $16 \%$ of the producers sell cheese through agents, as well as to the local shops, restaurants and hotels. The current price of cheese per kilogram ranges from 6 to 10 euros for hard, full-fat cheese. Our respondents most often (even $80 \%$ of them) sell cheese at this price range. The rest $20 \%$ sell cheese at a price of up to 5 euros or at a price that is higher than 10 euros.

In addition to cheese, livestock breeders sell other types of dairy products: milk, sour milk, urda (green cheese), whey, etc. One fifth of our respondents sells only cheese. In addition to cheese, almost half of our respondents sell milk, while the rest of them sell other dairy products (Figure 4). 
Figure 4. Structure of respondents by type of dairy products they produce

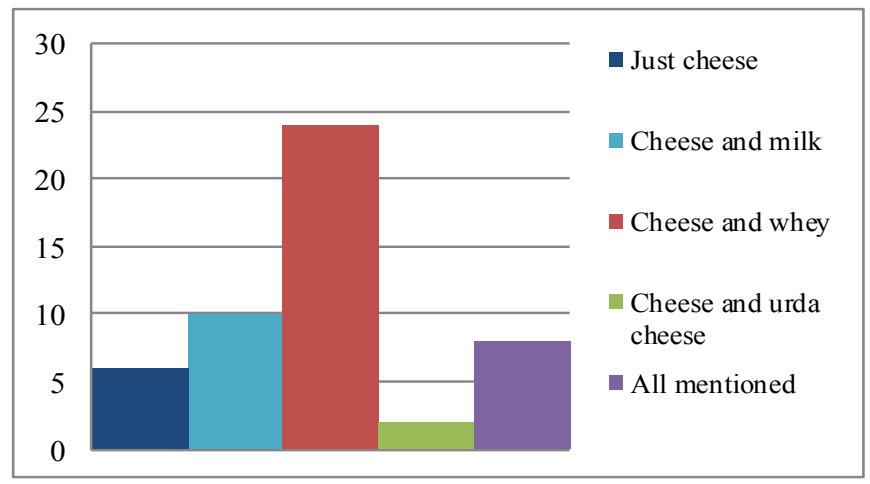

Source: authors' research

We have asked our farmers whether they consider existing cheese producers a competition. The majority, almost $60 \%$, answered that they have a few competitors, while fewer of them think that competition is big. A small number of them, $10 \%$ say that there is no competition at all. However, it is important to note that, besides the Serbs in the municipality of Strpce, the number of inhabitants of other nationalities involved in the production of this type of cheese is increasing. Also, in the last ten years in the Prizren area, an organized, factory production of cheese started. This cheese has a slightly different taste, so it is questionable whether it can be considered a competition to the cheese from Sirinićka Župa.

According to our research, when it comes to the profit earned from this job, it is not at the enviable level. This is confirmed by the fact that the livestock breeders generally have fewer livestock, which consequently leads to the production of smaller scale. Therefore, when considering all costs, work and labor, as well as the complexity of the production process, the profitability of this business is questionable. When asked if they can live from this job, the discouraging fact is that none of the respondent responded affirmatively. Most of them are visibly dissatisfied, and even $54 \%$ of them said that they can't make a living or barely can make a living from this job. The other respondents partially or in some way have settled their existence with this job.

In order to stimulate livestock breeding, which is already in the plan of all strategies for economic development of the municipality of Štrpce (Development plan of Štrpce municipality), assistance and incentives are also needed. In the last 18 years, after the arrival of international factors in this area, to this day, large funds have been allocated for the improvement of agriculture, livestock breeding, raspberry fostering, tourism, reduction of unemployment, or general economic development. According to the data of municipality of Strpce, livestock breeders and farmers from this municipality were participants in the various projects of the Provisional Self-Government in Priština and its ministries, local self-governments, Serbian institutions, the European Union and the international organizations and donors such as USAID, IOM CARITAS, the Danish Refugee Council, various agencies and others. The majority of the participants in our survey, $78 \%$ of them were not beneficiaries, while the rest $12 \%$ received support from local authorities, $6 \%$ from international donors and $4 \%$ from the government in Priština. 
The production expansion is also a basic prerequisite for both profit and livelihood. However, in order to increase the number of livestock units, it is necessary, above all, to have a certain capital and more importantly, to put a lot of work and effort around the livestock, which often presents big commitment for an average family. Therefore, it is not surprising that half of the respondents do not plan to expand. Still, the fact that the remaining $50 \%$ is considering some kind of expansion is the good news. Thus, $30 \%$ of them are thinking about additional livestock unit, $14 \%$ of them that they will surely expand their production with several livestock units, while $4 \%$ of them will start breeding other type of livestock. Only one respondent plans to expand, to double the number of livestock units and it is interesting to point out that this respondent is a female. This indicates to us that even in this business women show their entrepreneurial role and have a bold vision of the progress of their business. Given that a lot of residents of the municipality of Štrpce are young and middle-aged, as well as unemployed, livestock breeding and cheese production, with adequate technical assistance and financial incentives would be an ideal opportunity for the self-employment.

\section{Discussions}

Interesting facts were obtained by further analysis of the results. By determining the interdependence of all observed variables, we have confirmed some expected results, such as that the weekly sale of cheese depends directly on the number of the livestock units, the daily quantity of milk, weekly cheese production, as well as that it affects the satisfaction with the sales. Also, we came up to very interesting correlations that will help us in making conclusions of our research.

There is a statistically significant link between the variables "cheese production length" and "involved in livestock breeding" ( $p=0,007)$ with Pearson's correlation coefficient $r=0,579$, which means that with the increase in the length of cheese production, the number of household members involved in livestock breeding is also increasing. Also, a statistically significant result $(p=0,000)$ is the link between the "number of livestock units" and "the method of selling cheese" ( $r=0,493)$. Therefore, with the growth of the livestock units, the sale increases as well, because other than selling at home, other significant buyers appear, such as supermarkets, restaurants, hotels. Another highly significant result $(p=0,002)$ for the variable "number of livestock units" is its connection with "the method of cheese production" in which Pearson's coefficient of correlation is $r=0,426$, from which it can be concluded that with a greater number of livestock units, the method of producing cheese differs from the classical recipe (organic manufacture without additives, with citric acid production, recipe for kashkaval cheese). A similar example is the link between "daily milk quantity" and "the competition" ( $p=0,003, r=0,413)$. Therefore, one of the factors of increasing competitiveness in the market is reflected in the increase of daily production of milk.

The price of the product is an important factor in every business, including the production of cheese, which is also confirmed by this research. Thus, the "method of selling cheese" affects not only "the price of cheese", but the "weekly sale of cheese" as well. The massive the sales method is, the greater the price at which cheese is sold $(p=0,000$, $\mathrm{r}=0,508)$, and the weekly sale $(\mathrm{p}=0,001, \mathrm{r}=0,464)$. The results indicate that, if the entire amount of cheese, taken from livestock breeders, is purchased by bigger supermarkets or hotels, the price would be, which is very interesting, much higher, and the sales on a weekly basis would be increased, too. Also, an interesting data was obtained by the 
subsequent analysis that, if the competition on the market is higher, the price of cheese is higher $(\mathrm{p}=0,000, \mathrm{r}=0,574)$, too. The exact same parameters were obtained when determining the link between the "price of cheese" and "the production of other dairy products". Competition affects both, daily amount of milk and the satisfaction with the sales. The bigger the competition, the higher the quantity of produced milk on a daily basis $(p=0,003, r=0,413)$, as well as the satisfaction with sales $(p=0,000, r=0,557)$.

By examining the link between the variables "support" and "the length of cheese production", a statistically significant result was obtained $(p=0,005)$. It shows that Pearson's coefficient $r=-0,389$ is negative, which is interpreted in the way that our livestock breeders with long period of involvement in this business, mostly did not receive support, or obtained some, but not significant, from the local structures. On the other hand, the survey showed that new livestock breeders, involved in this job for a year, two or a few years, receive more support, predominantly from Serbian institutions, Kosovo and Metohija provisional institutions and international donors. The support also affects the "number of livestock units". The greater the support, the greater the number of livestock units $(\mathrm{p}=0,006, \mathrm{r}=0,586)$. Also, as the number of units is higher, the existence is, of course, better $(\mathrm{p}=0,001, \mathrm{r}=0,448)$. The analysis confirms the fact that when the weekly sales of cheese is higher, naturally the living of the livestock breeders and their families is better as well $(\mathrm{p}=0,004, \mathrm{r}=0,403)$.

Finally, the results that say a lot about the survival of this branch of agriculture in the municipality of Štrpce in the future, which was actually one of the main motivations for our research, show that with the increase in support for the livestock breeders, the plans for the expansion of this job $(p=0,004, r=0,665)$ would be far more serious. Undoubtedly, one of the most important roles in the future of livestock breeding in the municipality of Štrpce, and thus the future of the Šar cheese, have the respective municipal authorities. Livestock breeders in this region have the will to work, but they lack resources and someone to motivate them to work and improve the production as well as the method of placing dairy products. In order to improve the situation, it is necessary to work on increasing the capacities, that is, to increase the number of people involved in livestock breeding (Mladenović, 2017). The fact that, based on the Development Plan of the municipality of Štrpce, this is also the intention of local municipal structures is encouraging. It has already been mentioned that large funds are allocated for the economic development of agriculture in the municipality of Strpce, so we hope that the same will be redirected to the improvement of livestock breeding and production of milk and dairy products.

Šar cheese certainly represents the brand of the municipality of Štrpce. Therefore, it would be expected to work on its branding, that is, protection of its geographical origin. The certificate of authenticity and geographical origin will open many doors for this dairy product. As stated by Jovićević-Simin et al., (2016) the product bearing the title of geographical origin is synonymous with quality in the market. Branding of the Sar cheese would enable its sale not just on domestic markets, but on the foreign markets as well.

The municipality of Štrpce, located in one of the most famous national parks in this part of the Balkans, with its natural characteristics and preserved environment, has a great potential for organic production of various products: honey, medical herbs and fruits. With the production and placement of organic products on the local markets, the 
enclave can generate surplus income and thus create the economic basis for sustainable development of multifunctional agricultural households in Serbian enclaves (Maksimović et al., 2017). Another possibility for improving the production and sale of Šar cheese is the expansion of this activity in the field of healthy food and organic production of this dairy product. According to Popović-Vranješ et al. (2016), organic cheeses represent value added products that provide small milk producers with a sustainable source of income. They have the potential to revitalize farms, provide new jobs, and also to create new varieties of cheese with unique taste and new consumer experience. Changes in the production process in the direction of reducing environmental pollution and efficient use of resources in agriculture often result in higher yields, which together reflect the competitive advantage (Mladenović M. et al. 2017).

In rural areas, agrotourism is particularly important and in combination with organic food production it could represent a great opportunity (Pejanović et al., 2017). Rural tourism is a key factor in the activation and sustainable development of rural areas, which helps to preserve the local identity, tradition and customs, enforces homemade, traditional and eco-friendly production of healthy food (Đenadić et al., 2016). Municipality of Štrpce is widely known as a tourist center. Although after 1999, tourism is not at the same level as it was before, there is a potential for its development. For a rural area, such as this, the development of agrotourism would be a significant step towards overall economic development of this region. Šar cheese could definitely be one of the main products in the overall traditional gastronomic offer of this region.

Whichever of these methods of improving the production and sales of cheese the authorities select, the success is guaranteed. The reason for that is certainly the original aroma of Šar cheese, which is considered magical. Once you try it, you always come back for more. And, what is better for promoting a product than a satisfied customer?

\section{Conclusions}

The production of traditional, Šar cheese in the area of Štrpce municipality plays an important role in the economic and social development of both, entire municipality and its households. In this region, in the near past, every household was involved in the livestock breeding and cheese production, which however, nowadays is not the case. In a municipality of about 12,000 inhabitants, there are only about two hundred households that are following in the footsteps of their ancestors. Therefore, with the appropriate measures, it is necessary to preserve and improve the livestock breeding and production of milk and dairy products, in order to keep the Šar cheese in the leading position among the traditional products of this region in the future.

Based on the research and the analysis of all indicators, here are some of the authors' suggestions for improving the production and sales of cheese in the municipality of Štrpce:

- Increase the livestock units in existing households,

- Encourage the establishing of new small farms,

- Association of farmers in cooperatives,

- Improving production and sales,

- Implementation of European and world standards in the field of food production,

- Branding and protection of the geographical origin of cheese, 
- Expansion of production in the field of organic food,

- Development of agrotourism.

The improvement of livestock production, production and sale of Šar cheese is an ideal path towards economic development of a sustainable municipality. Given that nowadays sustainable development is considered a top priority, it should also be the guiding principle for the relevant local structures in the municipality of Štrpce. Since this municipality has predispositions for competing with more developed European countries, it would be a pity not to exploit this potential in the way that will contribute to the improvement of the quality of life for the entire community as well as every household involved in cheese production. Because, when people are able to work and live from their work, the conditions for stay and survival on the territory of their ancestors will be created too.

\section{Conflict of interests}

The authors declare no conflict of interest.

\section{References}

1. Bulajić, S., Ledina, T., Đorđević, J., Bošković, M., Matović, V., Marković, R., \& Baltić, M. (2017). Biopreservation of Traditional Raw Milk Cheese with an Emphasis on Serbian Artisanal Cheeses and their Historical Production. Meat Technology, 58(1), 52-61.

2. Bytyqi A., Berisha, K., Hamidi, A., Sulejmani, D., \& Thaqi, M. (2017). A Survey on Traditional Cheese Production and Diversity in Kosovo. Bulgarian Journal of Agricultural Science, 23(1), 42-48.

3. Cvijanović, D., Matijašević-Obradović, J., \& Škorić, S. (2017). The Impact of Air Quality Conditioned by Emission of Pollutants to the Development of Rural Tourism and Potentials of Rural Areas, Economics of Agriculture, 64(3), 871-885.

4. Đenadić, M., Muhi, B., \& Jovanović, D. (2016). Rural Tourism - Serbia's Missed chance, Economics of Agriculture, 63(2), 514-529.

5. Đurić, D., Ristić, J., Đurić, D., \& Vujanić, J. (2017). Export of Agricultural and Food Products in the Function of Economic Growth of Republic Serbia. Economics of Agriculture, 64(3), 887-900.

6. Eurostat, (2017). Milk and milk product statistics, Retrieved from: http:// ec.europa.eu/eurostat/statisticsexplained/index.php/Milk_and milk_product statistics (February 16, 2018)

7. Jovićević-Simin, M., Jovićević, P., \& Novaković, S. (2016). Appellations of geographical origin as a generator of national competitiveness. Economics of Agriculture, 63(2), 567-583. 
8. Maksimović, G., Milošević, B., \& Jovanović, R. (2017). Research of Consumer Attitudes on the Organic Food Consumption in the Serbian Enclaves in Kosovo. Economics of Agriculture, 64(3), 987-1001.

9. Mikić, Đ. (1988): Social and Economic Conditions of the Kosovo Serbs in the Nineteenth and Early Twentieth Centuries, Serbian Academy of Sciences and Arts, Belgrade. [Serbian: Микић, Ђ., Друштвене и економске прилике косовских Срба у ХІХ и почетком ХХ века]

10. Mladenović, K., Muruzović, M., Žugić-Petrović, T., Stefanović, O., \& Čomić, Lj. (2017). Isolation and Identification of Enterobacteriaceae from Traditional Serbian Cheese and their Physiological Characteristics. Journal of Food Safety, Wiley Online Library, 38(1), Retrieved from: http://onlinelibrary.wiley.com/ doi/10.1111/jfs.12387/full (February 17, 2018)

11. Mladenović, M. (2017). Sustainable Development and Investments in Municipality of Štrpce - Opportunities and Perspective. International Scientific Conference IOR-EDA 2017. Challenges of Sustainable Development - Economic and Social Aspect - Collection of Works, pp 655-670. [Serbian: Младеновић, М., Инвестиције и одрживи развој у општини Штрпце могућности и перспективе]

12. Mladenović, M., \& Arsić Lj. (2017), Green Economy Important Tool for Measuring the Competitive Advantage on the National Economy. Economic Outlook, 19(2), 81-99. [Serbian: Младеновић, М., Арсић, Љ., (2017), Бенефити зелене економије у функцији повећања конкурентске предности нациналне економије]

13. Pejanović, R., Glavaš-Trbić, P., \& Tomaš-Simin, M. (2017). Problems of Agricultural and Rural Development in Serbia and Necessity of New Agricultural Policy. Economics of Agriculture, 64(3), 1619-1635.

14. PM Food \& Diary Consulting, (2014). World Cheese Market 2000-2020, 14-17 Retrieved from: http://www.pmfood.dk/upl/9735/WCMINFORMATION.pdf (February 06, 2018).

15. Popović-Vranješ, A., Paskaš, S., Kasalica, A., Jevtić, M., Popović, M., \& Belić, B. (2016). Production, Composition and Characteristics of Organic Hard Cheese. Biotechnology in Animal Husbandry, 32(4), 393-402.

16. Razvojni plan opštine Štrpce, Retrieved from: http://helvetas-ks.org/ wp/wp-content/uploads/2013/08/OP\%C5\%A0TINSKI-Razvojni-Plan\%C5\%A0trpce.pdf (February 16, 2018).

17. Zekić, S., Mijić, J., Jakšić, D., \& Milenković, I. (2016). Profitability Gap in the Milk Production Chain: Evidence from Serbia. Economics of Agriculture, 63(2), 485-499. 